\title{
IMPLICATIONS OF CRUDE OIL EXTRACTION ON AGRICULTURE AND LIVELIHOOD IN OIL PRODUCING RURAL COMMUNITIES IN NIGERIA
}

\author{
Inibehe George UKPONG ${ }^{1 *}$, Ekemini $O B O K^{2}$
}

\author{
Address: \\ ${ }^{1}$ Department of Agricultural Extension and Management, Federal Polytechnic, Ekowe, Bayelsa State, Nigeria. \\ ${ }^{2}$ Department of Crop Science, University of Calabar, Nigeria \\ * Corresponding author email: inibeheukpong@gmail.com
}

\begin{abstract}
Activities of the oil and gas $(\mathrm{O} \& \mathrm{G})$ industry directly influence the natural potentials of the ecosystem and human livelihood. In particular, the impacts of crude oil extraction grossly interfere with the daily economic life of man and the natural environment. This study evaluates people's perception of the implications of crude oil extraction on agriculture and people's livelihood in oil producing rural communities in Nigeria with particular focus on the Niger Delta region, an area where most onshore and offshore crude oil extractions are carried out. The bias in this study came from the fact that crude oil is mainly either extracted or transported across rural communities in the region through water routes and/or arable lands, the population here almost solely depends on natural resources - water and land - for their daily livelihood. Findings suggest that livelihood sources in the region are under evident direct threat of pollution and other impacts of the $O \& G$ industry. Results obtained from the descriptive analysis of 446 respondents indicate a perception of high impact of crude oil extraction on food prices $(74.7 \%)$, food safety $(60.5 \%)$, crop yield $(48.2 \%)$ and animal production $(28.3 \%)$. The results of the Ordered Probit regression analysis suggest that farmers and fishermen are more vulnerable or mostly affected by impacts of crude oil extraction in the region. The study thus opined that adequate mitigation of negative impacts of crude oil extraction would promote improved food safety, affordable food supply and improved household income in oil producing rural communities. Therefore, the O\&G industry should intensify its commitments towards mitigating undesirable implications of exploration and extraction activities by $O \& G$ companies in the oil producing areas. In a bit to mitigate prevailing livelihood problems in the Niger Delta region, there is a need for O\&G companies and government to provide necessary compensations, trainings and other support to help the rural people sustain their livelihood. In addition, all stakeholders in the $O \& G$ ind ustry should collaborate with academic and research institutions to promote research in agriculture towards achieving improved food production and food safety in areas affected by impacts of crude oil extraction.
\end{abstract}

Keywords: Crude oil, agriculture, livelihood, rural communities, Nigeria JEL: Q1, Q4, Q5

\section{INTRODUCTION}

Oil and gas $(\mathrm{O} \& \mathrm{G})$ are valuable natural resources with economic potentials that support the livelihoods of the people. Unfortunately, the hazards associated with the industry have remained a global concern and a controversial issue in global debates about the existence of a 'resource curse'. For some countries, the O\&G ind ustry is the lifeblood of their economies, but for others, it has arguably been a curse, causing environmental pollution and having a negative impact on people's livelihoods (Watts, 2004). These issues question the efficiency of the resource as a viable economic resource and sustainable source of energy in a world already threatened by global warming, climate change and socioeconomic problems. However, it seems difficult to evaluate the trade-offs between the benefits and negative impacts of oil wealth (Opukri \& Ibaba, 2008). The Niger Delta region is the base of Nigeria's $O \& G$, and a major source of national revenue (Ikelegbe, 2001; Adekola et al., 2015). But the O\&G industry in Nigeria has been described as exploitative and a resource 'curse' paradox - causing poverty, destruction of environmental resources and poor rural economic development (Ibeanu, 2000; Okoko, 1999). It has been blamed for its pollution, income loss and the poor livelihood of people in the oil producing communities (Eregha \& Irughe, 2009; Opukri \& Ibaba, 2008).

The production of O\&G has brought wealth and economic growth while causing poverty among a large population in the Niger Delta. It has heightened community hostility towards the multinational oil companies. This has resulted in insecurity leading to violent protests, militancy and kidnappings, which remain issues of concern to the Nigerian government and international community (Ikelegbe, 2001; Watts, 2004). The Niger Delta region is an agrarian society where majority of the people depend heavily on agriculture and natural resources for their livelihood (Uyigue \& Agho, 2007; Taft \& Haken, 2015). Farming, forestry and fishing are a part of the major traditional economic activities of the rural people, including those living within oil producing communities (Adeyemo \& Zuofa, 2010; Ekpebu \& Ukpong, 2012). 
The O\&G industry is in constant competition for land, forest and water resources with negative effects on agriculture and human livelihoods (Osuji \& Onojake, 2004). There is documented evidence that $O \& G$ drilling in the region affects agriculture and other traditional livelihoods, resulting in poverty, unemployment and migration (Essien \& John, 2010; Gaughran, 2009). As an oil producing region, the Niger Delta remains potentially vulnerable to numerous environmental problems with consequent impacts including health and food safety issues, as well as other socioeconomic problems (Idemudia, 2009). Hence, there is a need to protect the environment and improve the livelihoods of people living within the region and other parts of the country. This has been an issue of concern to environmentalists, the government and general public (Zagi, 2002; Nwilo \& Badejo, 2005). The growing impact of the O\&G industry in the Niger Delta has increased concerns over the years. The frequency of oil pollution in the Niger Delta makes the region one of the most severely oil-spill impacted regions in the world (Frynas, 2001). There are numerous reports on biodiversity and natural habitat losses and other environmental problems in the region as a result of $O \& G$ production. In particular, studies have shown increased pollution of the mangrove ecosystem in the Niger Delta region as a result of oil spills, as well as a decline in biodiversity and dramatic loss of species in most oilproducing areas (Zabbey \& Uyi, 2014; Luiselli \& Akani, 2003; Osuji \& Onojake, 2004). Poor regulation of operations of $\mathrm{O} \& \mathrm{G}$ industry in the region have contributed to environmental hazards, including $O \& G$ pipeline explosions, gas flaring and oil spills; with consequent damage to land, crops, animals, forest and water resources. Oil spills and pipeline explosions are major sources of pollution and cause severe damage to the environment with negative economic implications for the people (Han \&Weng, 2010; Oliver-Smith, 1996; Sklavounos \& Rigas, 2006). It has also been reported that oil production in the Niger Delta has also caused health problems, a higher cost of living and loss of aquatic resources (Bhua \& Ukpong, 2018).

Nevertheless, efforts have been made over the years by the government and oil companies to improve the wellbeing of the people in oil producing areas so as to promote economic recovery, security, and cordial relationships between the people and the multi-national oil companies in the region (Idemudia, 2010). For instance, in an attempt to cushion the effect of environmental hazards and socioeconomic problems associated with O\&G production, O\&G companies have also adopted measures, including payment of compensation to affected individuals and communities, alongside taking other corporate responsibilities (Oando, 2009). Despite these measures, the region has remained vulnerable to $O \& G$ related environmental problems and economic hardship (Ukpong, et al., 2017). Pipeline explosions continue to happen, coupled with pollution caused by frequent oil spills, resulting in contamination of valuable water resources and land (Kadafa, 2012). These problems have resulted in legal tussles and a strained relationship between the communities and oil companies, triggering violent protests by youths, attacks on oil installations, militancy and kidnapping of oil workers. The high rate of insecurity in the region has remained an international concern over the past three decades (Azaiki, 2009; Etekpe, 2007; Omofonmwan \& Odia, 2009). Insecurity, conflicts and social unrest exacerbated by a poor socioeconomic situation and environmental problems caused by the O\&G ind ustry in the region remain (Akpan et al., 2012), this points to the failure of existing mitigation measures and policies to address the main concerns of the people.

Against this background, this study aims to investigate the livelihood and agricultural implications of the negative impacts of crude oil extraction in oil producing rural communities in Nigeria. Specifically, the study aimed to achieve the following objectives: to assess people's perceptions of the impacts of crude oil extraction in oil producing rural communities; to determine any possible statistical relationship between socioeconomic characteristics of the people and their perceptions of the impacts of crude oil extraction in oil producing rural communities; to determine if occupational designation of the respondents has any influence on their perception of the impacts of crude oil extraction in oil producing rural communities; and to identify occupational groups that are typically vul nerable to the impacts of crude oil extraction in oil producing rural communities.

A number of previous studies, theoretical reviews, reports and books have documented issues of pollution and other impacts of the O\&G industry, including (Payne \& Elliott, 2005; Abii \& Nwosu, 2009; Azaiki, 2009; Essien \& John, 2010). The overall arguments center on the fact that despite the huge revenues from crude oil, people who live within the oil producing communities still face economic difficulties. Some have labelled this a 'resource curse' created by the O\&G industry operating under poor regulations, resulting in poverty, social problems and environmental pollution in the Niger Delta region (Gaughran, 2009; Ibeanu, 2000; Uyigue \& Agho, 2007). The unsatisfactory responsiveness by the government and O\&G companies to the demands of the people, coupled with negligence and poor monitoring of crude oil extraction activities by the government have also been blamed for the hazards generated by the O\&G industry, which has also led to insecurity in the oil-rich region (Frynas, 2001).

The operations of the O\&G industry have brought about changes that affect the traditional means by which people make their livelihoods (mainly in the rural oilproducing communities). The Niger Delta region is a mainly agrarian society where the majority of the people depend almost solely on the environment (natural resources) and agriculture (mainly farming), fishing and forestry activities including gathering from the wild, hunting, and lumbering (Okonkwo et al., 2015; Akujuru \& Ruddock, 2014).

In this article, we will focus on people's perceptions of the impacts of the $O \& G$ industry with emphasis on externalities and resource-curse issues as a result of Crude oil extraction. The study thus based its findings on the assumption that the $O \& G$ industry affects the environment negatively, thus impacting negatively on the livelihood 
which is inseparably dependent on the natural environment.

Negative impacts of oil pollution usually get worse in the marine environment as oil could be washed or easily transported over a wide area by moving waters which cause damage to aquatic organisms along the coastal plains (Heintz et al., 2000; Islam \& Tanaka, 2004). Oil contamination may persist in the marine environment for many years, with measurable effects which could last for decades after the event (Kingston, 2002).

The activities of the oil and gas industry cannot be disentangled from the normal processes of the physical environment on which human livelihood is based. The impacts of crude oil extraction are thus grossly entangled with the daily economic life of the people. Needless to over emphasize that crude oil extraction produces environmental and economic costs, the consequences of which leaves rural coastal population highly vulnerable to economic misfortune. Therefore, while, there is a need to emphasize the economic importance of crude oil drilling to both producers and the consuming public, valuing the realistic socioeconomic or livelihood costs on the people is inevitably important (O'Rourke \& Connolly, 2003). The need to suggest solutions to the negativities generated from the processes of crude oil extraction thus forms the basis for this extract.

This study was proposed with the following hypotheses:

(i) There is no statistical relationship between socioeconomic characteristics of the respondents such as age, gender, educational level, family size, income and occupation, and their perceptions of the impacts of crude oil extraction in oil producing rural communities.

(ii) Occupational designation of the respondents does not influence their perception of the impacts of crude oil extraction in oil producing rural communities.

(iii) There is no occupational group that is typically vulnerable to the impacts of crude oil extraction in oil producing rural communities.

\section{DATA AND METHODS}

This study was conducted in three states of the Niger delta region in Southern Nigeria including Rivers, Bayelsa and Akwa Ibom states. The Niger Delta is where the bulk of crude oil and gas are drilled in Nigeria. Data were collected through structured survey questionnaires administered to 446 respondents selected from 15 rural communities ( 5 communities in each state) within the oilproducing region, including Chokota community, IgboEtche, Alesa-Eleme, Obigbo, Biara, Edo, Iko, Mkpanak, Unyenge, Ukpenekang, Odi, Imiringi, Etiama, OkotiamaGbarain, Ogboibiri. An average of 30 respondents was selected from each of the communities. Questionnaires were distributed at random through the door to door procedure. Distribution of questionnaires was aided by trained field assistants accompanied in most cases by community volunteers. Besides the descriptive approach employed in presenting the results of people's ranking of the impacts of crude oil extraction, ordered probit analysis was also used to evaluates the influence of socioeconomic characteristics of the respondents on their perceptions of the impacts.

\section{RESULTS AND DISCUSSION}

This section presents and discusses the results of the questionnaire survey on people's perceptions of the impacts of the crude oil extraction in oil producing rural communities in the Niger Delta.

\section{Ranking of Impacts of the $O \& G$ Industry}

Responses were assessed using four attributes; food safety, food prices, crop yield and animal production. A five-point Likert scale was used for the rating which ranged from 'no impact', to 'very high impact'; the results are presented in Figure 1.

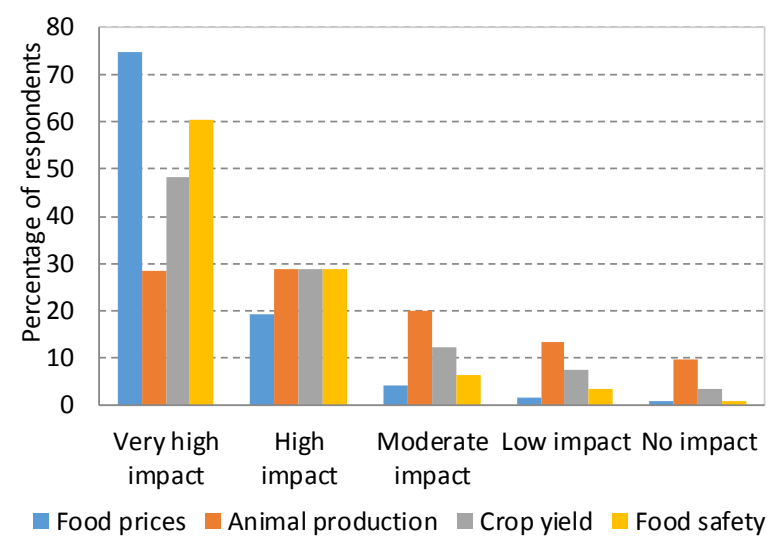

Figure 1: Ranking of Impact of the O\&G Industry Note: Total responses $=446$.

Figure 1 indicates that majority of the respondents perceived that crude oil extraction has either 'high' or 'very high' impact on food prices, food safety, crop yield and animal production, with $74.7 \%, 60.5 \%, 48.2 \%$ and $28.3 \%$ particularly indicating 'very high impact' on food prices, food safety, crop yield and animal production respectively. This shows a wide awareness of the negative impacts of crude oil extraction among rural population in the region, suggesting obvious widespread negative footprints of the O\&G industry on people's livelihood and food security in the region. Access to safe and affordable food, and price stability can contribute to equity and poverty alleviation by helping to reduce the vulnerability of poor people to shocks in food prices and availability (Timmer, 2000). Food price fluctuation can reduce economic growth with implications for the living standards of rural households. Food price is therefore a critical issue in addressing socioeconomic and livelihood problems of the people, especially in the rural communities where there is evident high income inequality and poverty. For poor households that cannot afford land for subsistent farming, access to food and choice of safe food depends largely on their levels of income. Hence, food market price and the ability to afford food at the prevailing price, have a direct impact on the quantity and quality of food accessible to a household. Therefore, households that cannot afford the desired food due to high prices may face hunger and strained income 
leading to poverty. These views depict with the realities in rural oil producing communities as about $75 \%$ of the respondents blame high food prices on the impacts of crude oil extraction in the region.

Crop yield is important in evaluating changes in the environment, as the health of crops and output also depends on several environmental factors, including soil quality. Oil pollution affects soil fertility and crop yield which is a direct threat to food security. In communities such as rural oil producing communities in the Niger Delta where most people depend almost solely on farming for their livelihood, persistent negative impacts on crop yield can result in severe cases of hunger and poverty. As indicated in Figure 1, over $48 \%$ of the respondents perceived that crude oil extraction is having a 'very high impact' on crop yield, which also confirms the reports that certain outcomes of the O\&G industry, particularly pollution from oil spills have 'a statistically significant effect (negative impacts) on crop yield' in oil producing areas (Inoni $\boldsymbol{e t}$ al., 2006). The Niger Delta region as an agrarian society is characterized by farmers who engage in crop and animal production, as well as off-farm activities including sales and marketing of agricultural products. There is no doubt that crude oil related pollution affects food safety in oil producing areas, and there is a tendency for polluted food items to infiltrate food chain across the region, hence, mitigation of negative impacts of crude oil extraction would promote improved food safety, increased food production and rural household income in oil producing rural communities. In view of these results, it is therefore important that the O\&G industry's social responsibilities should be more focused on these issues, especially to promote agricultural production to enhance food security and affordable food.

\section{Ordered Probit Analysis of People's perception of Impacts of Crude Oil Extraction}

Four variables were used for the analysis; food prices (IFP), crop yield (ICY), ani mal production (IAN) and food safety (IFS). The description of the socioeconomic variables is presented in Table 1. The different levels of impact are designated as 'Thresholds' in the model, such that a higher threshold level represents a high level (or severity) of impact, such as; threshold = 1 (no impact), threshold $=2$ (low impact), Threshold $=3$ (moderate impact), threshold $=4$ (high impact), and threshold $=5$ (very high impact). Severity of the dependent variable (levels of impact) increases from 1 (no impact) to 5 (very high impact), hence, a positive coefficient suggests the likelihood of a higher level of impact (or more severe impact). High levels of impact, therefore, represent high negative impact on the variable specified. In other words, higher levels of impact imply higher severity of negative effects of crude oil extraction. The goodness-of-fit information (Likelihood index and $\mathrm{R}^{2}$ values) and other parameter specifications for the ordered probit model are presented in Table 1. The summary statistics of the respondents' rating of the impact as generated by the model is presented in Figure 1.

Table 2 shows the ordered probit model estimates for People's perception of the impacts of crude oil extraction. The results indicate a positive relationship between income and people's perception of the impact on food safety, suggesting that perception of severity of the impact of crude oil extraction on food safety is likely to increase with higher levels of income. This implies that people of comparatively high income are likely to be more conscious of the quality and safety of the food they buy.

Table 1 Descriptive Statistics of Variables used in the Ordered Probit Analysis

\begin{tabular}{|c|c|c|c|c|}
\hline Variable & Label & Description and coding & $\begin{array}{l}\text { Mean } \\
(\mathrm{N}=446)\end{array}$ & $\begin{array}{c}\text { Standard } \\
\text { Deviation }\end{array}$ \\
\hline Gender & GEN & $\begin{array}{l}\text { Gender specifications of the respondents } \\
1=\text { Male } \\
0=\text { Female }\end{array}$ & 0.65 & 0.48 \\
\hline $\begin{array}{l}\text { Educational } \\
\text { Levels }\end{array}$ & EDU & $\begin{array}{l}\text { Educational status of the respondent } \\
1=\text { Formal education } \\
0=\text { Non-formal education }\end{array}$ & 0.86 & 0.35 \\
\hline Age & AGE & $\begin{array}{l}\text { Age of the respondent ranging from } \\
18-64 \text { years, labelled as a continuous variable (Covariates). }\end{array}$ & 40.04 & 11.01 \\
\hline Family size & FSI & $\begin{array}{l}\text { Family size of respondent ranging from } 1 \text { to } 10 \text { people, } \\
\text { labelled as a continuous variable (Covariates). }\end{array}$ & 4.08 & 2.25 \\
\hline Income & INC & $\begin{array}{l}\text { Monthly income of respondents ranging from N750 to } \\
\text { N150000, labelled as a continuous variable (Covariates). }\end{array}$ & 23952.30 & 26678.78 \\
\hline Occupation & $\mathrm{OCC}$ & $\begin{array}{l}\text { Occupation/occupational status of the respondents } \\
1=\text { Farming, } 2=\text { Government worker, } \\
3=\text { Oil company worker, } \\
4=\text { Other company worker, } 5=\text { self-employed; } 6= \\
\text { Unemployed; } 7 \text { = Student; } 8=\text { Fishing }\end{array}$ & 4.20 & 2.14 \\
\hline Thresholds & & $\begin{array}{l}\text { Levels of impacts (ordinal data form) } \\
1=\text { No Impact; } 2=\text { Low Impact; } 3=\text { moderate Impact; } 4= \\
\text { High Impact; } 5=\text { Very High Impact }\end{array}$ & & \\
\hline
\end{tabular}


Table 2: Ordered Probit Model Estimation for People's perception of the impacts of the O\&G Industry

\begin{tabular}{|c|c|c|c|c|}
\hline Variable & $\begin{array}{c}\text { Impact on food } \\
\text { safety (IFS) }\end{array}$ & $\begin{array}{l}\text { Impact on food } \\
\text { prices (IFP) }\end{array}$ & $\begin{array}{l}\text { Impact on crop } \\
\text { yield (ICY) }\end{array}$ & $\begin{array}{l}\text { Impact on animal } \\
\text { production (IAN) }\end{array}$ \\
\hline AGE & $0.011(0.008)$ & $-0.008(0.009)$ & $-0.001(0.007)$ & $-0.006(0.007)$ \\
\hline FSI & $-0.046(0.034)$ & $0.003(0.038)$ & $0.003(0.031)$ & $0.034(0.030)$ \\
\hline INC & $6 \mathrm{E}-6 * * *(3.2 \mathrm{E}-6)$ & $-5.4 \mathrm{E}-6(3.3 \mathrm{E}-6)$ & $3.81 \mathrm{E}-6(2.9 \mathrm{E}-6)$ & $-1.1 \mathrm{E}-6(2.8 \mathrm{E}-6)$ \\
\hline $\mathrm{GEN}=0$ & $-0.146(0.121)$ & $0.131(0.140)$ & $-0.082(0.111)$ & $-0.147(0.108)$ \\
\hline $\mathrm{EDU}=0$ & $-0.310(0.189)$ & $0.383(0.272)$ & $-0.049(0.173)$ & $-0.084(0.164)$ \\
\hline $\mathrm{OCC}=1$ & $-5.354 *(0.275)$ & $-4.221 *(0.391)$ & $1.450 *(0.335)$ & $0.002(0.339)$ \\
\hline $\mathrm{OCC}=2$ & $-6.543 *(0.261)$ & $-5.363 *(0.284)$ & $-0.146(0.339)$ & $-0.990 *(0.358)$ \\
\hline $\mathrm{OCC}=3$ & $-6.267 *(0.293)$ & $-5.136 *(0.330)$ & $0.159(0.365)$ & $-0.869 *(0.380)$ \\
\hline $\mathrm{OCC}=4$ & $-6.219 *(0.287)$ & $-5.961 *(0.287)$ & $-0.128(0.364)$ & $-1.175^{*}(0.382)$ \\
\hline $\mathrm{OCC}=5$ & $-6.158 *(0.213)$ & $-5.318 *(0.237)$ & $0.011(0.302)$ & $-0.715^{*}(0.324)$ \\
\hline $\mathrm{OCC}=6$ & $-5.951 *(0.228)$ & $-5.436 *(0.253)$ & $-0.030(0.333)$ & $-0.994 *(0.353)$ \\
\hline $\mathrm{OCC}=7$ & $-6.292 *(0.000)$ & $-5.973 *(0.000)$ & $-0.071(0.337)$ & $-8.12 *(0.356)$ \\
\hline $\begin{array}{l}\text {-2Log } \\
\text { Likelihood } \\
\text { Pseudo R }{ }^{2}\end{array}$ & $834.602 *$ & $613.972 *$ & $1184.482 *$ & $1309.739 *$ \\
\hline Cox \& Snell & 0.100 & 0.130 & 0.153 & 0.103 \\
\hline Nagelkerke & 0.115 & 0.166 & 0.162 & 0.108 \\
\hline McFadden & 0.053 & 0.091 & 0.059 & 0.036 \\
\hline Observations & 446 & & & \\
\hline
\end{tabular}

Note: Asymptotic standard errors (SE) in parentheses. Levels of significance: *** $P \leq 0.10 ; * * P \leq 0.05 ; * P \leq 0.01$. Threshold specifications: 1 = No Impact; $2=$ Low Impact; 3 = Moderate Impact; $4=$ High Impact; 5 = Very high Impact. Last variable (fishing $=8$ ) is set as reference variables in the model.

People with a comparatively higher income can afford safer food alternatives, which may be either foreign products or food brought in from other regions, possibly more expensive due to transportation or other marketing costs. On the other hand, low income people may be more vulnerable to food safety impacts, as they may have little choice in seeking alternative food due to constrained finances. The estimate also indicates that fishermen more than other people perceived as very high the impact of crude oil extraction on food safety and food prices, which may be linked to the high impact of oil pollution on the marine environments that affects fish and other seafood, resulting in loss of fishermen income and household food insecurity. These facts cannot be overemphasized owing to the devastating and fast spreading impacts of oil pollution in the marine ecosystem.

The results show a positive and significant coefficient of OCC $=1$ (farming), for ICY (impact on crop yield) and a positive but not significant coefficient of IAN = Impact on animal production, indicating that compared to fishermen (and perhaps, other occupational groups), farmers are mostly affected by, or most vulnerable to, the impacts of crude oil extraction. These findings may be connected with the fact that farmers suffer greater losses during pipeline explosions and oil spills on land that pollute and destroy farmlands. These results also corroborate the findings that farmers and fishermen seem to be the most vulnerable to environmental problems caused by oil and gas extraction in oil producing rural communities in the Niger Delta, (Ukpong et al., 2017). Therefore, all stakeholders in the O\&G industry should intensify their commitments toward mitigating undesirable implications of exploration and extraction activities by $\mathrm{O} \& \mathrm{G}$ companies in the oil producing areas.

In summary, in view of the hypotheses on which this study was based, the results indicate a statistical relationship between socioeconomic characteristics of the respondents such as age, gender, educational level, family size, income and occupation, and their perceptions of the impacts of crude oil extraction in oil producing rural communities. The results also suggest that occupational designation of the respondents influence their perception of the impacts of crude oil extraction in oil producing rural communities. Also, the results also suggest that occupational groups such as farming and fishing are typically vulnerable to the impacts of crude oil extraction in oil producing rural communities.

\section{CONCLUSION}

Activities of the oil and gas (O\&G) industry cannot be unlinked from the ecosystem and human livelihood. In particular, the impacts of crude oil extraction grossly entangle with the daily economic life of man and its environment. The bias in this study comes from the fact that crude oil is mainly either extracted or transported through water routes, arable lands and rural communities whose majority of its population are almost solely dependent on the environmental natural resources for their livelihood. There is no gainsaying to emphasize that rural population are subsistent farmers thus, produce the bulk of food they consume and depend mainly on natural water 
sources for their drinking water. It is thus obvious that rural population are frequently deprived of their natural sources of food and economic culture. The very reason the O\&G industry should be more committed to leveraging the causes of pollution and other impacts in these areas. Also, it is needless to over emphasize that the worrisome trend of rural poverty in Nigeria could be greatly mitigated if rural population are made to enjoy and fully utilise a serene, productive and pollution free environment. Rather, rural population in oil producing areas continues to face glaring food safety issues, and are left in the state of economic quagmire, thus making them vulnerable to food insecurity and poverty.

Findings of this study indicates very high impact of crude oil extraction on the people's livelihood in oil producing rural communities. Thus, there are obvious negative implications for the Niger Delta region whose rural population almost solely depend on the natural environment for agriculture (food production), forestry, hunting and fishing, as their main sources of livelihood. These livelihood sources are under evident direct threat of pollution and other impacts of crude oil extraction. There is therefore, a need to mitigate these impacts and salvage the deteriorating implications on people's livelihood, and the environment should be given a prompt attention by the government and the oil industry.

Besides food security issues, the results suggest that oil pollution has impacted on the quality and safety of food crops and seafood in the region, which suggests that pollution might infiltrate food chain in the region. This poses food safety and health risks to the people of the region and other parts of the country if urgent mitigation measures are not taken. In the event of an oil spill, it is possible that food crops get contaminated on farmlands and seafood from polluted waters might be marketed across the region. Thus, a significant reduction in pollution and other negative impacts of the industry would promote food safety, increased food production and availability of food at affordable prices in the region.

It is necessary that oil and gas companies adopt all necessary measures to tackle all possible and avoidable negative implications of Crude oil extraction in the region, by adopting recommended best drilling practices and global standards to promote protection and sustainability of the natural environment. Also, in a bit to mitigate prevailing livelihood problems in the Niger Delta region, there is a need for $\mathrm{O} \& \mathrm{G}$ companies and government to provide necessary compensations, trainings and other support to help the rural people sustain their livelihood. In addition, all stakeholders in the O\&G industry should collaborate with academic and research institutions to promote research in agriculture towards achieving improved food production and food safety in areas affected by impacts of crude oil extraction.

\section{ACKNOWLEDGEMENT}

Authors acknowledge the supervisory assistance from Professor Kelvin Balcombe and Dr. Francisco Areal of the University of Reading, United Kingdom, during the period of this research

\section{REFERENCES}

ABII, T. A. and NWOSU, P. C. (2009). The Effect of OilSpillage on the Soil of Eleme in Rivers State of the NigerDelta Area of Nigeria. Research Journal of environmental sciences, 3(3), 316-320. DOI: 10.3923/rjes.2009.316.320 ADEKOLA, O., MITCHELL, G. and GRAINGER, A. (2015). Inequality and ecosystem services: The value and social distribution of Niger Delta wetland services. Ecosystem Services, 12, 42-54. DOI: https://doi.org/10.1016/j.ecoser.2015.01.005.

ADEYEMO, A. and ZUOFA, O. (2010, May, 23-27). Food Security in Bayelsa State: The Challenges. Paper presented at the 45th Annual Conference of the Science Association of Nigeria, Niger Delta University, Bayelsa State, Nigeria.

AKPAN, P. U. (2014). Oil Exploration and Security Challenges in the Niger-Delta Region: A Case of Akwa Ibom State, Nigeria. IOSR Journal of Research \& Method in Education, 4(2), 41-48.

AKUJURU, V. A. and RUDDOCK, L. (2014). Incorporation of Socio-Cultural Values in Damage Assessment Valuations of Contaminated Lands in the Niger Delta. Land,3(3), 675-692. DOI: https://doi.org/10.3390/land3030675.

AZAIKI, S. (2009). The Evil of Oil. Ibadan, Nigeria: YBooks (A Division of Associated Book Makers Nigeria Limited.

EKPEBU, I. D. and UKPONG, I. G. (2012). Rethinking Agricultural Development in Nigeria: Paradox of Oil Wealth. Bloomington, USA: Authorhouse.

EREGHA, P. and IRUGHE, I. (2009). Oil induced environmental degradation in the Nigeria's Niger Delta: the Multiplier effects. Journal of Sustainable Development in Africa, 11(4), 160-175.

ESSIEN, O. E. and JOHN, I. A. (2010). Impact of CrudeOil Spillage Pollution and Chemical Remediation on Agricultural Soil Properties and Crop Growth. J. Appl. Sci. Environ. Manage., 14(4), 147-154. DOI: http://dx.doi.org/10.4314/jasem.v14i4.63304

ETEKPE, A. (2007). The Politics and Conflicts over Oil and Gas in the Niger Delta. Port Harcourt, Nigeria: Tower Gate Resources.

FRYNAS, J. G. (2001). Corporate and State responses to anti-oil protesters in the Niger Delta. African Affairs, 100, 27-54. https://www.jstor.org/stable/3518371

GAUGHRAN, A. (2009). Oil Industry has brought Poverty and Pollution to Niger Delta, from http://www.amnesty.org [Assessed 21 Jan 2015].

HAN, Z. and ANDWENG, W. (2010). An integrated quantitative risk analysis method for natural gas pipeline network. Journal of Loss Prevention in the Process Industries, 23(3), 428-436. DOI: https://doi.org/10.1016/j.jlp.2010.02.003

HEINTZ, R. A., RICE, S. D., WERTHEIMER, A. C., BRADSHAW, R. F., THROWER, F. P., JOYCE, J. E. and SHORT, J. W. (2000). Delayed effects on growth and marine survival of pink salmon Oncorhynchusgorbuscha after exposure to crude oil during embryonic development. Marine Ecology Progress Series, 208, $205-$ 216. DOI: $10.3354 /$ meps 208205 
IBEANU, O. (2000). Oiling the friction: Environmental confict management in the Niger Delta, Nigeria. Environmental change and security project report, 6, 1932.

IDEMUDIA, U. (2009). Oil extraction and poverty reduction in the Niger Delta: a critical examination of partnership initiatives. Journal of Business Ethics, 90(1), 91-116. DOI: 10.1007/s10551-008-9916-8.

IDEMUDIA, U. (2010). Corporate social responsibility and the rentier Nigerian state: Rethinking the role of government and the possibility of corporate social development in the Niger Delta. Canadian Journal of Development Studies/Revue canadienned'études du développement, 30(1-2), 131-151. DOI: https://doi.org/10.1080/02255189.2010.9669285.

IKELEGBE, A. (2001). Civil society, oil and conflict in the Niger Delta region of Nigeria: ramifications of civil society for a regional resource struggle. The Journal of Modern African Studies, 39(03), 437-469. DOI: https://doi.org/10.1017/S0022278X01003676.

INONI, O.E., OMOTOR, D. G. and ADUN, F. N. (2006). The Effect of Oil Spillage on Crop Yield and Farm Income in Delta State, Nigeria. Journal of Central European Agriculture, 7(1), 41-48.

ISLAM, M. S. and TANAKA, M. (2004). Impacts of pollution on coastal and marine ecosystems including coastal and marine fisheries and approach for management: a review and synthesis. Marine pollution bulletin, 48(7), 624-649. DOI: https://doi.org/10.1016/j.marpolbul.2003.12.004

KADAFA, A. A. (2012). Oil exploration and spillage in the Niger Delta of Nigeria. Civil and Environmental Research, 2(3), 38-51.

KAN, H., CHEN, R. and TONG, S. (2012). Ambient air pollution, climate change, and population health in China. Environment international, 42, 10-19. DOI: 10.1016/j.envint.2011.03.003

KINGSTON, P. F. (2002). Long-term environmental impact of oil spills. Spill Science \& Technology Bulletin, 7(1), 53-61.DOI: https://doi.org/10.1016/S13532561(02)00051-8

LUISELLI, L. and ANDAKANI, G. (2003). An indirect assessment of the effects of oil pollution on the diversity and functioning of turtle communities in the Niger Delta, Nigeria. Animal Biodiversity and Conservation, 26(1), 5765.

NWILO, P. C. and ANDBADEJO, O. T. (2005, May). Oil spill problems and management in the Niger Delta. In International Oil Spill Conference (Vol. 2005, No. 1, pp. 567-570). American Petroleum Institute. DOI: https://doi.org/10.7901/2169-3358-2005-1-567

OANDO. (2008). Annual Report, Lagos, Nigeria: Oando Petroleum PLC.

OKOKO, E. (1999). Women and environmental change in the Niger Delta, Nigeria: Evidence from Ibeno. Gender, Place and Culture: A Journal of Feminist Geography, 6(4), 373-378. DOI: https://doi.org/10.1080/09663699924944

OKONKWO, C. N. P., KUMAR, L. and TAYLOR, S. (2015). The Niger Delta wetland ecosystem: What threatens it and why should we protect it?. African Journal of Environmental Science and Technology, 9(5), 451-463. DOI: http://dx.doi.org/10.5897/AJEST2014.1841

OLIVER-SMITH, A. (1996). Anthropological research on hazards and disasters. Annual review of anthropology, 303-328

DOI:

https://doi.org/10.1146/annurev.anthro.25.1.303

OMOFONMWAN, S. I. and ODIA, L. O. (2009). Oil exploitation and conflict in the Niger-Delta region of Nigeria. Journal of Human Ecology, 26(1), 25-30. DOI: https://doi.org/10.1080/09709274.2009.11906161

OPUKRI, C. and IBABA, I. S. (2008). Oil induced environmental degradation and internal population displacement in the Nigeria's Niger Delta'. Journal of Sustainable Development in Africa, 10(1), 173-193.

O'ROURKE, D. and CONNOLLY, S. (2003). Just oil? The distribution of environmental and social impacts of oil production and consumption. Annual Review of Environment and Resources, 28(1), 587-617. DOI: https://doi.org/10.1146/annurev.energy.28.050302.10561 7.

OSUJI, L. C. and ONOJAKE, C. M. (2004). Trace Heavy Metals Associated with Crude Oil: A Case Study of Ebocha-8 Oil-Spill-Polluted Site in Niger Delta, Nigeria. Chemistry \& biodiversity, 1(11), 1708-1715. DOI:

$10.1002 / \mathrm{cbdv} .200490129$

SKLAVOUNOS, S. and RIGAS, F. (2006). Estimation of safety distances in the vicinity of fuel gas pipelines. Journal of Loss Prevention in the Process Industries, 19(1), 24-31. DOI: https://doi.org/10.1016/j.jlp.2005.05.002

TAFT,P. and HAKEN, N. (2015). Niger Delta Overview. In Violence in Nigeria (pp. 9-50). Springer International Publishing. ISBN 978-3-319-14935-6

TIMMER, C. P.(2000). The macro dimensions of food security: economic growth, equitable distribution, and food price stability. Food Policy, 25(3), 283-295. DOI: https://doi.org/10.1016/S0306-9192(00)00007-5

UKPONG, I.G., INYEINYANG, M.M and OMWMOVIE, E.E. (2017). Impact of the Oil and Gas Industry in Nigeria: An evaluation of cases in the Niger delta. Journal of Biopesticides and Environment, 4(2), 2228.

UYIGUE, E. and AGHO, M. (2007). Coping with climate change and environmental degradation in the Niger Delta of southern Nigeria. Community Research and Development Centre Nigeria (CREDC).

WATTS, M. (2004). Resource curse? Governmentality, oil and power in the Niger Delta, Nigeria. Geopolitics, 9(1), 50-80.

DOI:

https://doi.org/10.1080/14650040412331307832

ZABBEY, N. and UYI, H. (2014). Community responses of intertidal soft-bottom macrozoobenthos to oil pollution in a tropical mangrove ecosystem, Niger Delta, Nigeria. Marine pollution bulletin, 82(1), 167-174. DOI: https://doi.org/10.1016/j.marpolbul.2014.03.002

ZAGI, M. (2002). Environmental Impact Assessment and the Nigerian Oil Industry: A Review of Experiences and Learnings. Paper presented at the SPE International Conference on Health Safety and Environment in Oil and Gas Exploration and Production. DOI: https://doi.org/10.2118/74074-MS 